\title{
ENGLISH AS A LENS INTO OUR CONTEMPORARY WORLD
}

\author{
Roberta Pires de Oliveira ${ }^{1^{*}}$ \\ ${ }^{1}$ Universidade Federal de Santa Catarina, Florianópolis, SC, Brasil
}

Ilha do Desterro is a periodical focusing on English, literature and cultural studies. Published by the English Graduation Program, PPGI, at Universidade Federal de Santa Catarina, in Florianópolis, Brazil, it is a journal of excellence (A1, Qualis CAPES), precisely because its publications adhere to the requirements for academic journals, and for internationalization as described in the national document of the area of letras and linguistics (Documento da área de letras e linguística, CAPES, Brasil, 2016a $)^{1}$. This volume testifies this academic excellence, while preserving a critical stance, since most (but not all) of the papers are in English and its contributors are from several universities in Brazil and abroad. Furthermore, some of the papers are proposals that involve partnership with education, aiming at contributing to the continuing education of language teachers, as well as to the improvement of curriculum and didactic resources for language learning (Brasil, 2016b). At last but not at least, the journal submits to the ethical commitments for research with human beings in humanities, in accordance with the normes in vigor, for both quantitative and qualitative methodologies (Brasil, 2016c). All of the papers that involve research with human beings were approved by local Ethic Commits.

Ilha do Desterro reflects the graduation structure found at PPGI, which, in turn, reproduces both the way graduation programs are institutionally organized in Brazil, via CAPES, our national agency that finances and evaluates our programs, and the way in which research in the area of language and literature is institutionalized in Brazil, via CNPq, our national agency for research: literature, associated with cultural studies, and language studies, congregating linguistics and applied linguistics. The journal publishes thematic and open issues that

\footnotetext{
" Professora titular do DLLV da UFSC, pesquisadora 1 do CNPq, participa da PPGI e da PPGL. Sua pesquisa centra-se em questões de semântica/pragmática das línguas naturais a partir de uma perspectiva formal. Tem desenvolvido estudos com base em experimentos e mais recentemente em processamento por falantes bilíngues. Seu objeto de estudos é principalmente o português brasileiro, tendo como panorama a variação, comparado tanto ao inglês, tomada como língua "metro", quanto com línguas indígenas do Brasil, em especial Rikbaktsa (Macro-Jê). Coordena dois grupos de pesquisa no CNPq, sendo um deles internacional. Trabalha em projetos de extensão para professores de língua. E-mail: ropiolive@gmail.com ORCID: https://orcid.org/00000002-4946-7205.
} 
alternates volumes on literature-cultural studies and linguistics-applied linguistics. This open issue is about English either from a linguistic or an applied linguistic perspective. English is certainly one of the most well studied languages in linguistics, which has led contemporary linguistics to critically call attention to the danger of scientific research on universal grammar being centered around just one language (Matthewson, 2003). English may be a 'metric' that is used to compare other languages - it is a SVO language which does not have bare singulars, and is a non-pro-drop language -, but we must be careful to not build a meta-language that represents English grammar. Here lies the crucial role of taking into consideration the variety of languages in the world.

English is also the language that is officially taught at schools in Brazil, where most of the students are speakers of Brazilian Portuguese. This situation of 'contact' raises a number of issues. How are languages represented in our mind/brains? Are there technologies that may benefit learning an 'additional' language? Why should English be the official additional language in Brazil? A great part of the research at PPGI spins around teaching English in classrooms, understanding it as a process of becoming bilinguals. Furthermore, English, as any language, conveys ways of living. Concepts model our thinking and acting. What else justifies considering literature and language as different research areas? Discourse analysis and critical thinking highlights the role of teachers who are tutoring the most prestigious language in Brazilian society, allowing not only a better understanding of our contemporary societies, but also pointing to ways of emancipation. The way we behave in our everyday life, naturalizing ideas that have a history, are put into scrutiny. The process of internationalization of our graduate programs, imposed by our institutions, has English as the language of science. The critical analysis of the language used in advertisements to hire scientists uncovers science as business. Those are the themes the reader meets in the papers here gathered together, which compose a picture of the present challenging scenario in the field of language research.

"An investigation on the role of referentiality in the interpretation of relative clauses in Brazilian Portuguese" by Gitanna Bezerra, a free researcher in postdoctorate at PPGI, opens this issue on language, not only because it shows the importance of looking at several languages in order to understand how they are stored and represented in our minds/brains, but because it focuses on Brazilian Portuguese, the native language of most of our students. It presents the results of an off-line experiment conducted to investigate the influence of referentiality on the interpretation of relative clauses in Brazilian Portuguese, comparing it to the results for English. The literature shows that relative clauses associated with complex NPs seem to be preferentially attached to the noun that is referential, independently of the language. However, languages vary with respect to the way referentiality is conveyed. Is the referentiality effect explained in terms of the discourse representations (Gilboy, Sopena, Clifton and Frazier, 1995), and thus independent of the grammar, or is it dependent on the syntacticsemantic representations that are developed for the sentences? The results of this 
experiment on Brazilian Portuguese points to the syntactic-semantic structure underlying the complex NPs. This is an important contribution to the field of language processing.

The next three papers discuss pedagogical tools as well as teaching materials used to teach English in classrooms in Brazil. "A pedagogia translíngue e a elaboração de tarefas na formação integral do educando brasileiro", by Anamaria Welp, from Universidade Federal do Rio Grande do Sul, and Ofelia García, from University of New York, confirms the international academic cooperation in humanities, producing original thoughts about language teaching that might contribute to our language practice in classrooms. The paper proposes a model for the practical application of 'translanguaging pedagogy' (García and Wei, 2015), which relies on the fact that bilinguals naturally use languages for different activities. Combined with task-based teaching, offering a contribution that aims to "decolionally" provide opportunities for task performance through English and Portuguese. The proposal ties together emerging linguistic understandings in the classroom to conceptual knowledge arising from collaborative tasks, drawing on the notion of language as a repertoire.

"Discurso e sociedade na aula de inglês como língua adicional", by Désirée Motta-Roth, from Universidade Federal de Santa Maria, and Helena Vitalina Selbach, also from Universidade Federal de Santa Maria, presents a teaching proposal for English as an additional language, adopting the concepts of discourse (language as social practice in discourse genres) as constitutive of social life and, thus, essential to issues pertaining to the human experience. The authors assume the postmethod pedagogy (Kumaravadivelu, 2006, among others), the educational perspective of work projects, and sustained content-based teaching approach, to theoretically support their proposal for an interdisciplinary project, seeing as a possible approach from which a variety of situated pedagogical proposals can depart to attend to different teaching contexts.

Reinildes Dias, from Universidade Federal de Minas Gerais, and Ana Emília Turbin, from Universidade de Brasília, in "The two 'multis' and the multiliteracies pedagogy "shaking hands" in the Brazilian English Public Education for teens", analyze one English school textbook. Textbooks have a long tradition in the Brazilian public sector of education, and most often they are the only pedagogical resources in an English classroom. The authors carefully inspected two units of a textbook from a textbook series for teens that was approved in 2020 by our national program for evaluating textbooks. They adopt the multiliteracies pedagogy as in the London school (Cope and Kalantzis, 1996), and assume the active role learners play in learning as the theoretical background for their evaluation, which relies on the documentary methodology within the qualitative paradigm. They argue that the units follow the principles of the two "multis" and the cycle of knowledge processes, point out aspects that might be improved, and give some suggestions for English teachers.

Donald Davidson's philosophy of radical interpretation (Davidson, 1973) understands that interpreting is the skillful art of translating the language of the 
other into our own. Although from a different tradition, this is the theme of the paper by Aurielle Gomes dos Santos, a PhD student at Universidade Federal de Campina Grande, and Sinara de Oliveira Branco, from Universidade Federal de Campina Grande, which presents the challenges posed by literary translation in general, in the translation of invented items. The paper analyzes the strategies used by Katrina Dodson in translating "The complete stories" by Clarice Lispector, when dealing with invented expressions, new lexical creations which may be difficult even for a native speaker. Those are called Clarice specific items. In "Itens clariceanos-específicos em The complete stories: uma análise das estratégias de tradução de expressões criadas pela autora", the authors first identified, and classify those items according to the strategies used in the translation. The results show that the balance between the use of foreignizing and domesticating translation strategies bends towards maintaining the strangeness provoked by the original creations. They conclude that the translator welcomes the foreigner through what Ricoeur (2006, p. 10) calls linguistic hospitality: "where the pleasure of dwelling in the other's language is balanced by the pleasure of receiving the foreign word at home, in one's own welcoming house."

The last two papers make us critically reflect on graduate systems in today's world. "Marketization of Japan-Based Higher Education Advertisements", by Mukaddam Khaitova, Toyama Prefectural University, and Theron Muller, from University of Toyama, Japan, presents an insightful picture of the higher education system in Japan, considered to be a society that is largely closed to influences from outside. The authors investigated 81 job advertisements in English through a critical discourse analysis (Fairclough, 1993), examining the extent to which these advertisements exhibit characteristics of "marketization". They follow Lowrie and Hemsley-Brown's (2011) definition of marketization as a force that "challenges stakeholders with radical change encompassing issues of power, funding, labour, markets, and complexity" (Lowrie \& Hemsley-Brown, 2011, p. 1081 apud the authors) that reshapes and redefines the academic profession. They conclude that Japan-based higher education is marketized, exhibiting the features of neoliberal ideologies and free-market conventions. Japanese higher education, at least in its job advertisements, exhibits colonization by market forces, reinforcing the worldwide spread movement of turning research and education into business.

In "Teacher education in EMI settings: a partial view from Brazil", Telma Gimenez, from Universidade Estadual de Londrina, and Marilice Marson, PhD student from the same Universidade Estadual de Londrina, reflect on English Medium Instruction (EMI) via an analysis of EMI preparatory courses offered in Brazilian higher education institutions. The aim is to identify the courses offered by Brazilian institutions to support EMI teaching. They conducted a search on Google and Google Scholar to map publications between 2016-2020 about those courses. They argue that EMI has increased around the world, especially in Europe and Southeast Asia, but conclude that it is still very initial in Brazil, where research has concentrated on ways of implementing and improving it (Baumvol and Sarmento, 2019). The authors claim that those initial efforts to 
prepare lecturers for EMI contexts in Brazil present a great variety of purposes, duration and approaches, with many research gaps that are in need of further development.

The seven articles that make up this issue indicate the variety of subjects and theoretical approaches in contemporary applied linguistics and linguistics, reflecting on socio-political issues of extreme importance to our lives as well as on more theoretical issues.

\section{Notes}

1. See for a detailed description of how Ilha do Desterro has fulfilled those requirements see Tomitch and Silveira 2020

\section{References}

Baumvol, Laura. Knijnik and Sarmento, Simone. (2016). A internacionalização em Casa e o uso de inglês como meio de instrução. In: M. S. Beck; M. E. Moritz; M. L. M. Martins; V. Heberle (org.), Echoes: Further Reflections on Language and Literature. Florianópolis: UFSC, p. 65-82.

Brasil (2016a). Ministério da Educação. Coordenação de Aperfeiçoamento de Pessoal de Nível Superior. Diretoria de Avaliação. Documento de Área 2016. Área de avaliação: Letras e Linguística. Brasília, DF: CAPES. Available at https:// www.capes.gov.br/images/documentos/Documentos_de_area_2017/41_LETR_ docarea_2016.pdf. Retrieved: 21 Jan. 2020.

Brasil. (2016b). Ministério da Educação. Base Nacional Comum Curricular. Brasília: MEC, Consed, Undime, 2016. 651p. Available at: http://basenacionalcomum. mec.gov.br/images/BNCC_EI_EF_110518_versaofinal_site.pdf. Retrieved: 21 Jan. 2020.

Brasil (2016c). Resolução no 510, de 7 de abril de 2016. Available at: https://www. in.gov.br/materia/-/asset_publisher/Kujrw0TZC2Mb/content/id/22917581

Cope, Bill and Kalantzis, Mary. (1996). The New London Group Manifest. 1996. A pedagogy of multiliteracies: Designing social futures. Harvard educational review, 66(1), 60-93.

Davidson, Donald. Radical Interpretation. (1973) Dialectica Vol. 27, No. 3/4, pp. 313-328.

Fairclough, Norman. (1993). Critical discourse analysis and the marketization of public discourse: The universities. Discourse and Society, 4, 133-168.

García, Ofelia and Wei, Li. (2015). Translanguaging: language, bilingualism and education. Basingstoke, UK: Palgrave Macmillan.

Gilboy, Elizabeth, Sopena, Joseph, Clifton, Charles and Frazier, Lee. (1995). Argument structure and association preferences in Spanish and English complex NPs. Cognition, 54, 131-167.

Matthewson, Lisa 2003. How Natural is the Meta-Language? Comments on Durst's Paper. Theoretical Linguistics 29:263-274.

Kumaravivelu, B. (2006) Understanding language teaching: from method to postmethod. New Jersey: Lawrence Erlbaum Associates, Inc., Publishers, 2006.

Ricoeur, Paul. (2006) On translation. London, New York: Routledge, 2006.

Tomitch, Leda and Silveira, Rosane. 2020. Introduction. Ilha do Desterro, v. 73, n.1, pp. 11-18. 